\title{
How Do We Prepare to Teach? Exploring Science Lecturers' Authentic Approaches to Teaching in Higher Education
}

\section{Deesha Chadha ${ }^{1}$}

Accepted: 28 October 2020/Published online: 4 November 2020

(C) The Author(s) 2020

\begin{abstract}
In this paper, science lecturers' perspectives on how they authentically prepare to teach are explored, to establish how academic development practices can better support them. Science lecturers in higher education do not always feel comfortable engaging with pedagogical training initiatives, often finding the ideas presented confusing, nontransferable and of little benefit to them. Models of pedagogical training suit institutional requirements and the generic principles of teaching in higher education. However, it is more useful to establish science lecturers' authentic preparation techniques and build academic practice models around these. At a research-intensive higher education institution (HEI) in the UK, a total of 64 science lecturers completed a 28-item survey about the authentic values, beliefs, and the practices that inform and support their preparation as teachers. The collated survey responses were analysed through a statistical package for social sciences (SPSS), and a linear regression model was produced for self-reported confidence (used as a proxy for preparedness). Initial results pointed to the importance of enjoyment, being innovative and experimental, and demonstrating a good grasp of content for developing confidence. Receiving advice from education-based experts was a negative contributor to the confidence model as was pedagogical training unless it was part of a wider offering. However informal, supportive, peer-to-peer dialogue is deemed beneficial, highlighting the significant role communities of practice play in authentic preparation.
\end{abstract}

Keywords Academic practice $\cdot$ Authenticity $\cdot$ Confidence $\cdot$ Higher education $\cdot$ Science lecturers

Deesha Chadha

d.chadha@imperial.ac.uk

1 Department of Chemical Engineering, Imperial College London, 1M17A ACEX, South Kensington Campus, London SW7 2AZ, UK 


\section{Introduction and Background}

In this paper, the authentic mechanisms through which science lecturers develop their practice as teachers are explored through a preliminary investigation. This work has come about through conversations with academics from science disciplines who have attended pedagogical training organised by an academic development unit at a research-intensive HEI in the UK and have found such training difficult. Therefore, the attempt is being made to 'enter the mind' of the science lecturer to establish where this difficulty comes from and how it might be appropriately addressed. In the following few sections, the case is being made for exploring this question in the first place, highlighting the significance of this work.

Part of the problem faced in higher education is that knowledge and belief about the purposes and goals for teaching science deeply influence orientations to teaching science - an idea that gains momentum as practice is influenced by what is already known and believed about teaching, learning and learners (Borko and Putnam 1996; Kember and Kwan 2000). Once a belief system has been set, it is very difficult to change it (Friedrichsen and Dana 2005) and usually there is no appetite to do so. However, this is not the whole story. By understanding someone's orientation, we are naturally limited to understanding their teaching behaviour, yet their values, beliefs and response to their contextual surroundings remain a mystery. These contextual barriers matter, for example large class sizes can hinder meaningful pedagogical change resulting in half-hearted efforts to engage with professional development activities (Hamilton 2018). In the UK especially, certain drivers have affected change, for example the introduction and subsequent increase of tuition fees, suggesting an increasing push towards getting students through and ensuring they are employable, which means that irrespective of their beliefs and best intentions, lecturers are often not encouraged to make concerted attempts to develop their teaching practices by their own students who 'just want to pass so I can get a job' resulting in the teaching of core topics becoming a means to an end (Guilbault 2018).

A second fundamental concern is that higher education teachers traditionally enter academia without teaching qualifications, but rather as accomplished researchers; they resort to tried and tested methods of teaching that they are most familiar with, which are often didactic and aimed at the transmission of knowledge (Handelsman et al. 2004). Furthermore, prior research highlights the fact that science lecturers are emotive about their teaching, displaying feelings of comfort with content and anxiety at the unpredictability of inquiry (Dreon and McDonald 2012). Following on from this, it is suggested that limited exposure to a student-centred learning environment often means that these educators would not naturally create one as teachers (Addy et al. 2015). The authors themselves do not view this situation as dichotomous; on numerous occasions, it has been observed that science teachers struggle with implementing active learning strategies in their classrooms, even though teaching by telling is outdated (Freeman et al. 2015). Science lecturers who conceive of teaching as transmitting information to students also conceive of student learning as information accumulation, dispelling the need for dialogical approaches (Fraser 2015).

In relation to what has been said about science lecturers, attention is now turned to academic developers. Academic development plays a central role in terms of preparing faculty to embrace their roles as teachers through practice development when it is targeted towards continual professional development (CPD) of learning and located within a disciplinary context (Boud and Brew 2013). Equally, researchers have argued that academic development works on the premise that critical reflection is a key determinant of how one develops their teaching practice (Carew et al. 2008). As science lecturers do not naturally create space for 
reflective dialogue within their disciplinary discourse - instead mastering cognitive thought processes such as learning facts and principles (Sawir 2011), it can often prove challenging for academic developers to work with scientists to encourage them in their reflection. Pedagogical training demands honesty, a willingness to share experiences and learn from them-there is no quick fix on offer. As has been mentioned, the danger here though is that academic developers become so fixated in the approach they have selected to support these science lecturers, failing to realise that they ignite confusion and are subsequently labelled unhelpful (Roxå and Mårtensson 2017). The lack of reflection among science lecturers is concerning as is the fact they find pedagogical training so unstructured. Given the constructivist nature of academic development practice, academic developers are somewhat obliged to understand where they are coming from and offer them support and guidance accordingly (Carew et al. 2008). As such, would it not be helpful to establish how science lecturers authentically prepare as teachers, building support mechanisms around these self-identified processes?

As part of this work, the notion of authenticity in this context needs to be defined. A definition of authentic taken directly from the Oxford Dictionary claims it means genuine, known to be true. A much earlier understanding of what this might mean in teaching is suggested by Patterson $(1973$; p103) who claims that 'the genuine teacher is, then not using a method or a technique as something outside himself for his methods or techniques are an integral part of himself'. With respect to the development of authentic teaching practice, definitions of authenticity rarely feature in literature; those that are available can be split into two categories. Palmer (1998) suggests that authentic practice is something which promotes student learning in traditional subjects, and yet equally, it is about empowerment and individualisation. Care (for students, the subject and oneself) is also a feature of authenticity in teaching according to a number of scholars, which are often reflected in notions of freedoms (albeit limited), engagement and self-worth (Palmer 1998; Noddings 2003; Dillard 2006). These ideas are embedded in an individual's values, beliefs, and positioning as a teacher. According to Kreber et al. (2007), authenticity is multi-faceted and there is an emphasis on relationships with oneself and others:

Authenticity in teaching involves features such as being genuine, becoming more selfaware, being defined by one's self rather than by others' expectations, bringing parts of oneself into interactions with students, and critically reflecting on self, others, relationships and context, and so forth. (p. 40-41)

Most significant for this work perhaps is this idea that authenticity in teaching practice is also constructive, developmental pedagogy (based on underlying principles, rather than instructive prescription) with emphasis placed on the nature of dialogue that exists within the teachinglearning environment (Baxter Magolda 2004). These ideas are essentially related to the processes one goes through to develop their authentic pedagogy of practice. Combining these two strands of thought, Cranton and Carusetta (2004) stipulate there are five categories through which we can define authenticity in taught practice: self (for example shows passion), other (for example students' interests), relationships (for example dialogue), context (for example knowledge of discipline) and critical reflection (for example critical examination of experiences). Building on this, Kreber (2010) emphasises the importance of personal theories of teaching (which encompass reflective critique and values) - all of which inform individuals' self-perception of authenticity. 


\section{Methodology}

Based on the background to this research and the notions of authenticity presented here, the central research question posed by this work is how do science lecturers authentically prepare for their roles as teachers? The interest lays in establishing patterns of behaviour, and relationships between various mechanisms, and to use the findings from the research to guide the support available to science lecturers from academic developers.

\section{Respondents}

In a preliminary study, a total of 64 members of staff in various positions (referred to as science lecturers for the purpose of this work), and with varied teaching responsibilities aligned to science or science-related fields (see Table 1 for details denoting demographics of participants), completed surveys at a research-intensive institution in the UK to establish their authentic preparation for their role as teachers.

The study included individuals with different levels of teaching experience from graduate teaching assistants (GTAs) right through to professors.

\section{Instrument}

In accordance with the broad definition of authenticity provided, the 28-item survey (Fig. 1), was split into three semi-distinct constructs, which broadly accommodate these ideas:

Construct 1 (items 1-10): personal and professional values and beliefs (e.g. student learning and care)

- The items included here are related to how the lecturer philosophises about learning and teaching within their context (items 3 and 4), and the pedagogical theories they aspire to (items 5-7). Additionally, in broaching the notion of care/attention, this is denoted by establishing the value and worth of professional development (items 8-10), enjoyment of teaching (item 1) and the lecturers' sense of preparedness in the role (item 2).

Construct 2 (items 11-20): positioning (e.g. empowerment and individualism)

- Within this construct, the items centre around how much lecturers feel empowered to setup their own teaching structure (items 11 and 12), their autonomy with respect to the organisation of their teaching, for example type and frequency (items 13-17), and how they self-identify in the role of lecturer (items 18-20).

Construct 3 (items 21-28): process of preparation (e.g. developmental pedagogy and relationships)

- For construct 3, the items all relate to the support mechanisms that are ordinarily offered through academic practice initiatives (items 21-24), means through which individuals access constructive and supportive dialogue (items 25 and 26), and the drivers that can lead to self-awareness, reflection, and pedagogical change (items 27 and 28). 
Table 1 Demographics of respondents

\begin{tabular}{|c|c|c|c|}
\hline & $\begin{array}{l}\text { Years of } \\
\text { experience }\end{array}$ & Disciplines & Context of teaching \\
\hline Professors (10) & $10-39$ & $\begin{array}{l}\text { Maths } \\
\text { Chemistry } \\
\text { Physics } \\
\text { Nutrition \& Dietetics } \\
\text { Biology } \\
\text { Computer science } \\
\text { Biochemistry }\end{array}$ & $\begin{array}{l}\text { - Masters and PhD supervision } \\
\text { - Varying amount of lecturing to } \\
\text { undergraduates and Masters' students } \\
\text { - Running labs } \\
\text { - Head of Department }\end{array}$ \\
\hline $\begin{array}{l}\text { Senior } \\
\quad \text { lecturers/Readers (11) }\end{array}$ & $11-20$ & $\begin{array}{l}\text { Pharmacy } \\
\text { Nutrition \& Dietetics } \\
\text { Maths } \\
\text { Informatics } \\
\text { Forensic science } \\
\text { Genetics } \\
\text { Anatomy }\end{array}$ & $\begin{array}{l}\text { - Masters and PhD supervision } \\
\text { - Frequent lectures to undergraduates } \\
\text { and Masters' students } \\
\text { - Running labs, modules, and programmes } \\
\text { - Programme director }\end{array}$ \\
\hline Lecturers (4) & $3-9$ & $\begin{array}{l}\text { Computer science } \\
\text { Maths } \\
\text { Analytical chemistry } \\
\text { Nutrition \& Dietetics }\end{array}$ & $\begin{array}{l}\text { - Frequent lectures and lab } \\
\text { demonstrations (some topics are new) } \\
\text { to undergraduates and masters students } \\
\text { - } \mathrm{PhD} \text { supervision as } 1 \mathrm{st} / 2 \text { nd supervisors } \\
\text { - Module convenors }\end{array}$ \\
\hline $\begin{array}{l}\text { Post docs/Teaching } \\
\text { fellows (14) }\end{array}$ & $2-6$ & $\begin{array}{l}\text { Physics } \\
\text { Forensics } \\
\text { Environmental science } \\
\text { Genetics } \\
\text { Maths } \\
\text { Neuroscience }\end{array}$ & $\begin{array}{l}\text { - Regular tutorials with small groups of } \\
\text { undergraduates } \\
\text { - Occasional lab demonstrations } \\
\text { - Guest lecturing/supporting lecturers } \\
\text { - 'Informal' Masters supervision }\end{array}$ \\
\hline GTAs (25) & $1-3$ & $\begin{array}{l}\text { Informatics } \\
\text { Physics } \\
\text { Maths } \\
\text { Chemistry } \\
\text { Pharmacy } \\
\text { Genetics } \\
\text { Forensics } \\
\text { Nutrition \& Dietetics } \\
\text { Immunobiology }\end{array}$ & $\begin{array}{l}\text { - Occasional tutorials with small groups } \\
\text { of undergraduates } \\
\text { - Lab demonstrations }\end{array}$ \\
\hline
\end{tabular}

Ratio of male to female: 48 male and 16 female respondents. Ethnicity: 33 (White European/White other), 18 (Black/Asian/Ethnic), 13 (no data recorded)

Some of the information being gathered by the survey lies beyond the definitions of authenticity, for example types of students taught, sessions run, and how lecturers see themselves, to develop an appreciation of what the individual does, how they feel about their teaching load, and how they self-identify. Such information is useful in an academic practice context, as it is all built-in to the approach taken to understand and support the lecturer.

Participants were also invited to submit open-text comments in the survey if they wished to.

\section{Data Collection}

Data collection and analysis methods were approved by the institutional research ethics committee prior to the research being carried out - institutional reference number: LRS-15/ 16-3237. The survey used for this research underwent several revisions and was piloted on one occasion, with 3 science lecturers until considered a good representation of the constructs 
Percentage responses using 5-point Likert scale for 28 items of

\section{I enjoy teaching}

2. I am a confident teacher

3. I like to experiment with what I do as a teacher

4. I am an innovative teacher

5. My preferred method of teaching is enquiry-led

6. My preferred method of teaching is based around knowledge transfer

7. My preferred method of teaching is based around PBL

8. I am interested in my CPD as a educator

9. I am interested in my CPD as a researcher

10. I would be more interested in teaching if it carried greater weight, for example around promotions

11. It is important to deliver content to students

12. It is important to discuss concepts with students

13. I teach more often than I would like to

14. I teach less often than I would like to

15. I mostly supervise masters students

16. I mostly run labs

17. I mostly teach undergraduates

18. I define myself primarily as a scientist

19. I define myself primarily as a science educator

20. I define myself primarily as a researcher

21. I have learnt how to teach from being observed

22. I have learnt how to teach from talking to others in informal settings

23. I have learnt to teach from participating on a teaching programme

24. I have learnt how to teach from a combination of the above

25. I receive the best advice about teaching from disciplinary-based colleagues

26. I receive the best advice about teaching from teaching and learning based colleagues

27. Peer review is a valued mechanism through which $I$ develop my teaching

28. Student evaluation is a valued mechanism through which I develop my teaching
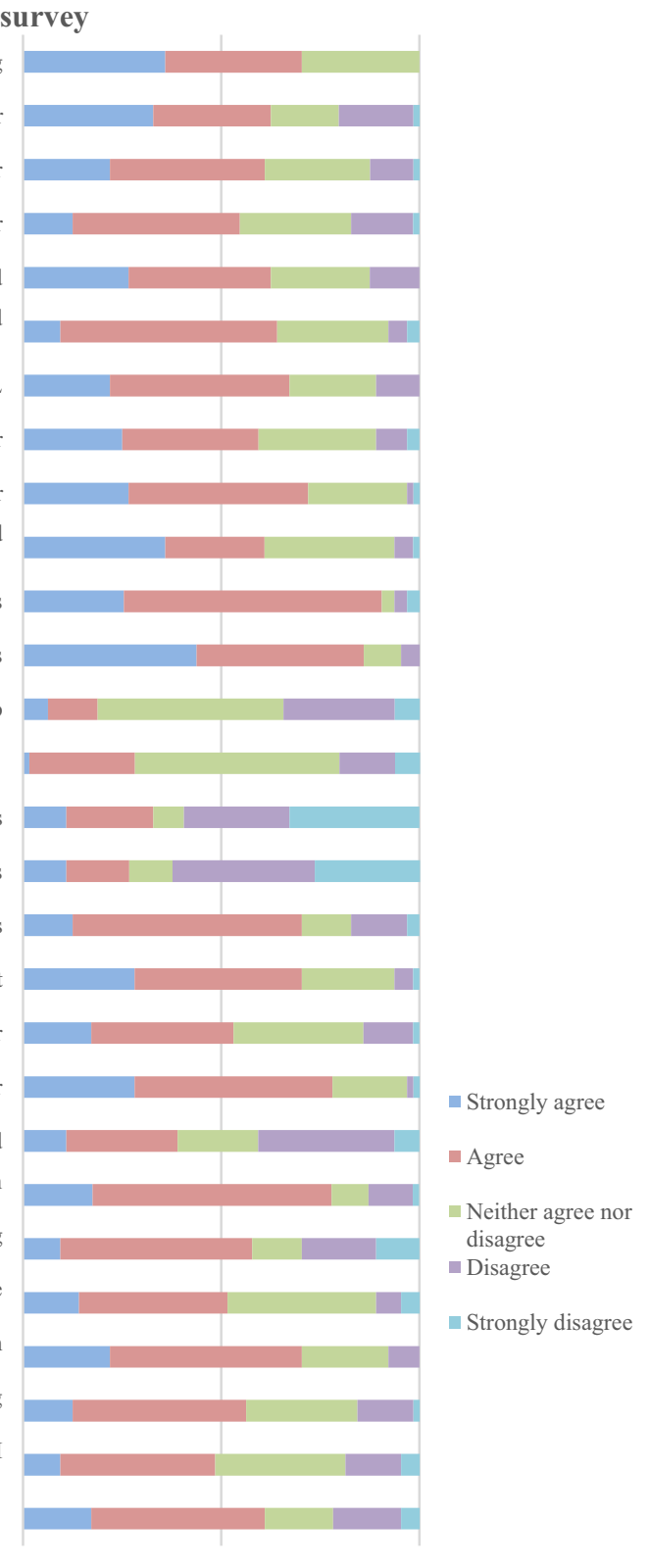

- Strongly disagree

Fig. 1 Response rates of participants by percentage for the 28-item survey

being explored. Respondents were recruited using two methods. Firstly, a student intern was provided with the contact details of colleagues personally known to the principal investigator, mostly senior lecturers/readers and professors who were individually approached to participate. Even though completed surveys were collated in person or returned via email, these were anonymised on receipt. Respondents were also recruited by the principal investigator, mostly 
GTAs, post docs and new lecturers during workshop sessions of an academic development programme. Respondents could participate with the research if they chose to, with responses being collected anonymously during the class itself.

\section{Data Analysis-1st Phase}

The responses were analysed using a 5-point Likert scale, with responses ranging from strongly agree to strongly disagree (Fig. 1). Figure 1 denotes the 28 items used in the survey and the initial response data, which has been calculated by percentage. Degrees of association between items were explored to establish whether there was positive or negative correlation between them. These relationships are rarely explored and yet could be important in developing the right support going forward, especially as effective academic practice is focused on making sense of the connected relationships between several support mechanisms and approaches. Correlation between the 28 items was established by initially assigning a numerical value to the 5 points of the Likert scale and uploading these into a spreadsheet manually: strongly disagree $(-1.0)$, disagree $(-$ $0.5)$, neither agree nor disagree $(0.0)$, agree $(+0.5)$ and strongly agree $(+1.0)$. Individual items were assigned separate columns and the associated numerical values inserted into the spreadsheet accordingly. The individual items (denoted as columns in the spreadsheet) were labelled and the programme run to ascertain degrees of association between items based on the Spearman Rho correlation coefficient; the closer the coefficient is to +1.0 , the greater the degree of association between items. Table 2 reveals the degrees of association between most items that feature in the survey (excluding items 13, 14, 16, 17, 18 and 20 as these items did not suggest significant correlations with other items).

Descriptive statistics of the items were also determined and are presented in Table 3.

\section{Data Analysis-2nd Phase}

An attempt has been made to model confidence (item 1 on the survey) against all other items that make up the survey using linear regression, in an attempt to make more concrete assertions in relation to the data and open up a discussion. Even though self-reported confidence does not equate to preparation, one often needs to feel confident before they feel they are adequately prepared. For example, one might be prepared to bake a cake because they have attained self-confidence from having understood instructions, having the right ingredients, etc. Previous studies in dental education have used self-perceived confidence as a proxy for preparedness (Smith et al. 2006; Gilmour et al. 2016), and a similar approach has been taken in this work based on the understanding that, in order to answer the central research question posed, it is subsequently important to explore the inter-relationships between confidence (as a proxy for preparedness) and other survey items and model this relationship. The predictor/independent variable (confidence) was then measured against the predicted/dependent variables (other items in the survey). In running regression analysis to generate the model(s), a confidence interval of $95 \%$ was set with an additional 'forward stepwise' requirement, meaning that several items were automatically excluded from the models generated, so fail to feature within the parameters defined for the regression modelling. 


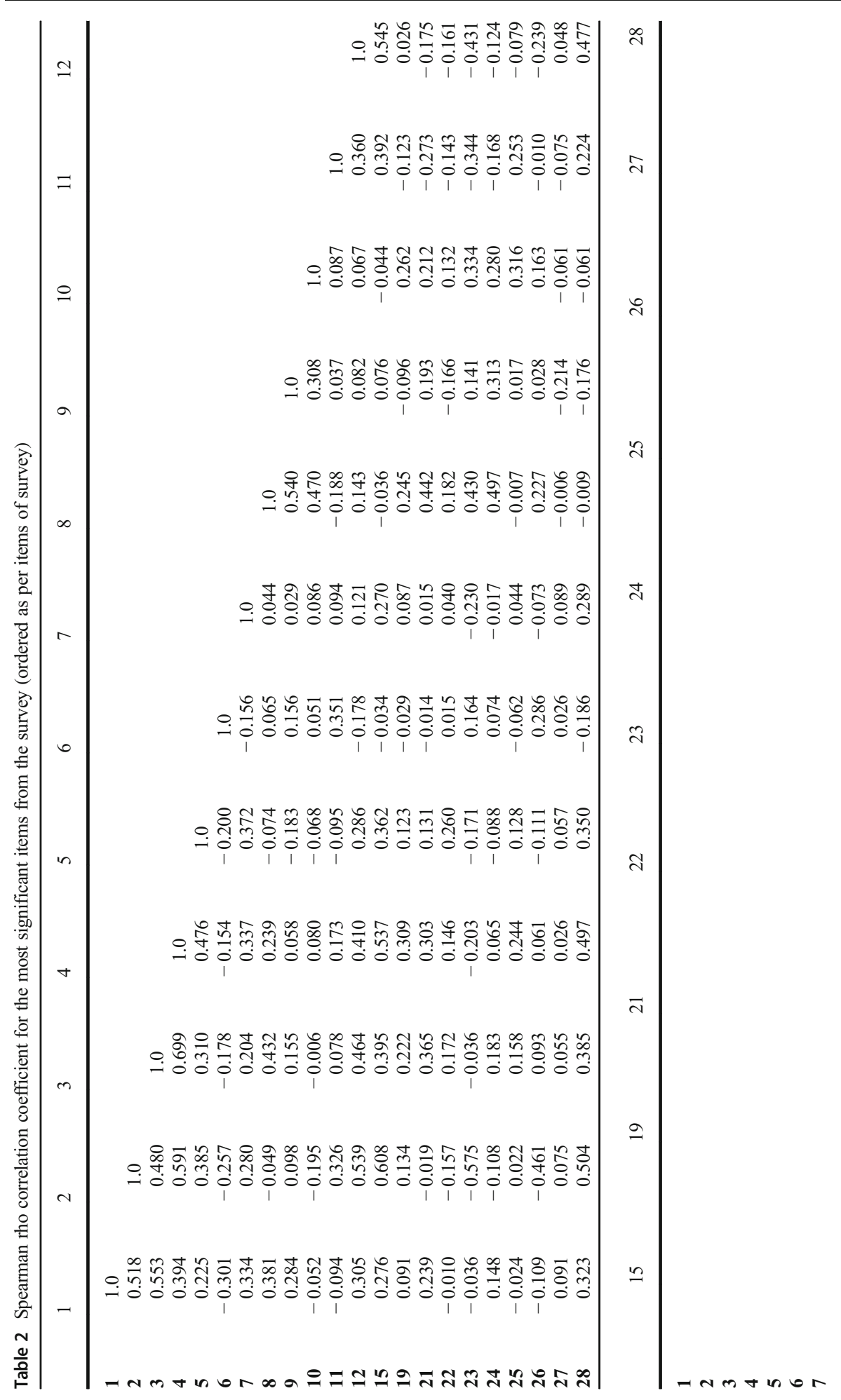

\section{Springer}




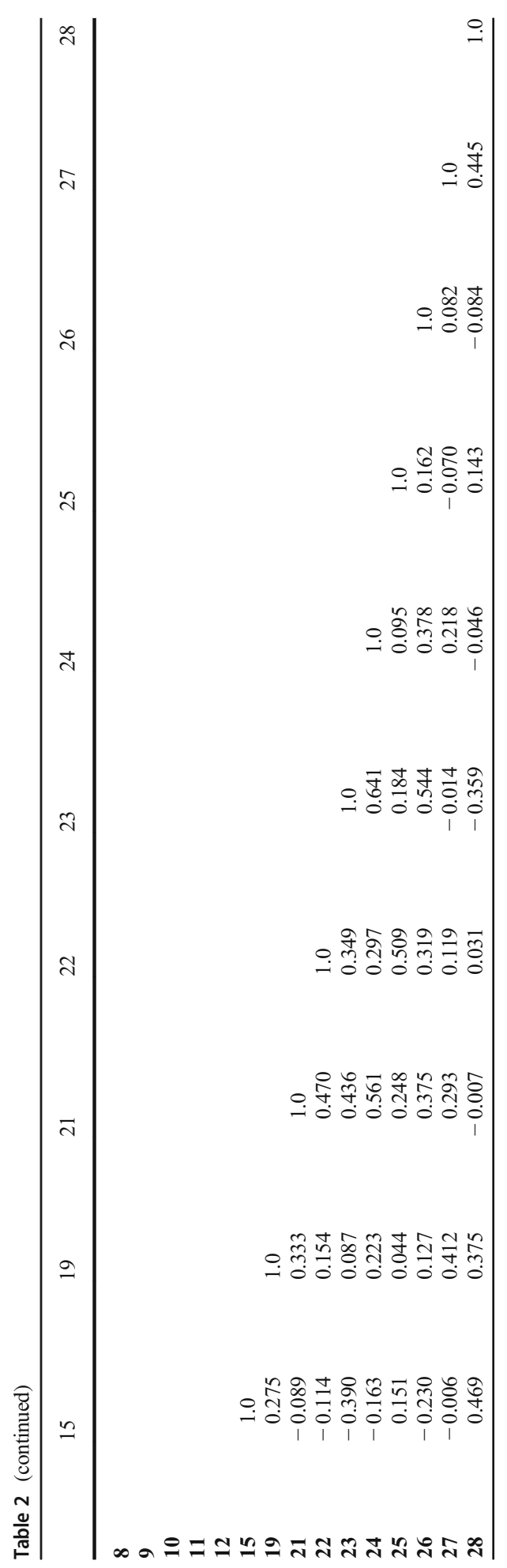


Table 3 Descriptive statistics for all the items (ordered as per items of survey)

\section{Mean Median Mode Standard Variance Kurtosis Range} deviation

\begin{tabular}{|c|c|c|c|c|c|c|c|}
\hline I enjoy teaching & .5313 & .5444 & 1.00 & .40703 & .166 & -1.479 & 1.00 \\
\hline I am a confident teacher & .3672 & .4500 & 1.00 & .57901 & .335 & -.796 & 2.00 \\
\hline $\begin{array}{l}\text { I like to experiment with what I do as a } \\
\text { teacher }\end{array}$ & .3438 & .3690 & 0.500 & .49501 & .245 & -.340 & 2.00 \\
\hline I am an innovative teacher & .2422 & .2667 & 0.500 & .47968 & .230 & -.433 & 2.00 \\
\hline $\begin{array}{l}\text { My preferred method of teaching is } \\
\text { enquiry-led }\end{array}$ & .3828 & .4103 & 0.500 & .49395 & .244 & -.898 & 1.50 \\
\hline $\begin{array}{l}\text { My preferred method of teaching is based } \\
\text { around knowledge transfer }\end{array}$ & .3125 & .3396 & 0.500 & .42258 & .179 & 1.669 & 2.00 \\
\hline $\begin{array}{l}\text { My preferred method of teaching is based } \\
\text { around problem-based learning }\end{array}$ & .3906 & .4186 & 0.500 & .48330 & .210 & -.511 & 1.50 \\
\hline $\begin{array}{l}\text { I am interested in my continual } \\
\text { professional development as an } \\
\text { educator }\end{array}$ & .3516 & .3780 & 0.500 & .51701 & .267 & -.110 & 2.00 \\
\hline $\begin{array}{l}\text { I am interested in my continual } \\
\text { professional development as a } \\
\text { researcher }\end{array}$ & 4688 & .4889 & 0.500 & .42608 & .182 & 0.910 & 2.00 \\
\hline $\begin{array}{l}\text { I would be more interested in teaching if } \\
\text { it carried greater weight, for example } \\
\text { around promotions criteria }\end{array}$ & .4453 & .4730 & 1.00 & .50487 & .255 & -.525 & 2.00 \\
\hline $\begin{array}{l}\text { It is important to deliver content to } \\
\text { students }\end{array}$ & .5317 & .5877 & 0.500 & .41999 & .176 & 1.722 & 2.00 \\
\hline $\begin{array}{l}\text { It is important to discuss concepts with } \\
\text { students }\end{array}$ & .6250 & .6727 & 1.00 & .40825 & .167 & .800 & 1.50 \\
\hline I teach more often than I would like to & -.0781 & -.1042 & 0.00 & .47324 & .224 & .228 & 2.00 \\
\hline I teach less often than I would like to & .0156 & .0500 & 0.00 & .42696 & .182 & .407 & 2.00 \\
\hline I mostly supervise master's students & -.2422 & -.3864 & -1.00 & .71265 & .508 & -1.258 & 2.00 \\
\hline I mostly run labs & -.2548 & -.3833 & -0.500 & .66662 & .444 & -.842 & 2.00 \\
\hline I mostly teach undergraduates & .3125 & .3778 & 0.500 & .49200 & .242 & .358 & 2.00 \\
\hline $\begin{array}{l}\text { I define myself primarily as a scientist or } \\
\text { engineer }\end{array}$ & .4531 & .4881 & 0.500 & .46049 & .212 & .415 & 2.00 \\
\hline $\begin{array}{l}\text { I define myself primarily as a science or } \\
\text { engineering educator }\end{array}$ & .2734 & .2841 & 0.500 & .48738 & .238 & -.445 & 2.00 \\
\hline I define myself primarily as a researcher & .5078 & .5400 & 0.500 & .41300 & .171 & 1.685 & 2.00 \\
\hline $\begin{array}{l}\text { I have learnt how to teach from being } \\
\text { watched }\end{array}$ & .0156 & -.0143 & -0.500 & .57714 & .333 & -1.044 & 2.00 \\
\hline $\begin{array}{l}\text { I have learnt how to teach from talking to } \\
\text { others }\end{array}$ & .4018 & .4659 & 0.500 & .45665 & .209 & .989 & 2.00 \\
\hline $\begin{array}{l}\text { I have learnt how to teach from } \\
\text { participating on a teaching programme }\end{array}$ & .1328 & .2308 & 0.500 & .59922 & .359 & -.791 & 2.00 \\
\hline $\begin{array}{l}\text { I have learnt how to teach from a } \\
\text { combination of the above }\end{array}$ & .2500 & .2708 & 0.00 & .48795 & .238 & .432 & 2.00 \\
\hline $\begin{array}{l}\text { I receive the best advice about teaching } \\
\text { from disciplinary-based colleagues }\end{array}$ & .4219 & .4444 & 0.500 & .42927 & .184 & -.259 & 1.50 \\
\hline $\begin{array}{l}\text { I receive the best advice about teaching } \\
\text { from teaching and learning-based col- } \\
\text { leagues }\end{array}$ & .2578 & .2826 & 0.500 & .47134 & .222 & -.292 & 2.00 \\
\hline $\begin{array}{l}\text { Peer review is a valued mechanism } \\
\text { through which I develop my teaching }\end{array}$ & .1719 & .2065 & 0.500 & .49776 & .248 & -.127 & 2.00 \\
\hline $\begin{array}{l}\text { Student evaluation is a valued } \\
\text { mechanism through which I develop } \\
\text { my teaching }\end{array}$ & .2578 & .3205 & 0.500 & .55629 & .309 & -.483 & 2.00 \\
\hline
\end{tabular}




\section{Validity and Reliability}

Having initially assessed for suitability, exploratory factor analysis (EFA) was conducted to determine construct validity. In the EFA, 2 items were unaccounted: I define myself primarily as a researcher, and I define myself primarily as a scientist. Neither item refers directly to teaching or education so perhaps this is expected, but equally the items are important in this research in understanding how the science lecturer views their work and their priorities. Internal reliability was established by determining the Cronbach alpha value $(\alpha)$ across all items, and across the 6 identified components. The overall Cronbach alpha value of 0.697 is considered acceptable (Taber 2018). The Cronbach alpha for components 3 and 6 are considered low, but as mentioned earlier, the survey items are a mergence between interpreted definitions of authenticity and information gathering. The validity and reliability data are provided in Table 4 .

With respect to construct validity in Table 4, some items indicate a high loading on multiple components, for example item 23-I have learnt to teach from participating on a teaching programme. This item, in particular, consists of many separate parts that taken together generally form the foundation of academic development programmes. Therefore, overlap with constructs 1,2 and 3 as a minimum is to be expected, as through these programmes lecturers explore their values and beliefs as teachers, address notions of teacher identity and prepare as teachers through strategies such as teaching observations and understanding pedagogy.

\section{Results}

In answering the central research question, it is important to consider initial preferences lecturers have for developing their taught practice and how they consider their position as teachers (raw data from surveys), the relationships between these aspects of teaching which serves as a helpful guide to academic developers who need to make connections between support mechanisms (correlation) and how authentic practice is developed (regression modelling). Figure 1 reveals some interesting insights, namely the degree of importance attached to engaging in conversation with others as a precursor for preparing to teach. Learning to teach by talking to others scored significantly higher in terms of positive responses (17.5\% strongly agree and $60.3 \%$ agree) when compared with learning to teach through being observed $(10.9 \%$ strongly agree and $28.1 \%$ agree) and participating with pedagogical training ( $9.4 \%$ strongly agree and $48.4 \%$ agree). In terms of the numbers of participants that reported these levels of agreement, this is given as learning to teach by talking to others (a total of 50 participants either strongly agree (11) or agree (39)), learning to teach through observation of others (a total of 25 participants either strongly agree (7) or agree (18)), and participating with pedagogical training others (a total of 37 participants either strongly agree (6) or agree (31)). It is worth noting that in terms of the nature of this conversation, more respondents received the best advice about teaching from disciplinary-based colleagues (21.9\% strongly agree and $48.4 \%$ agree) as opposed to those from more generic educational disciplines $(12.5 \%$ strongly agree and $43.8 \%$ agree). Open-text comments also reflected the importance of constructive dialogue:

It is the tricks and tips I've learnt from pretty much everyone that are priceless. I've noticed conversations around teaching are also becoming a lot more sophisticated. Just to add, one should never underestimate the importance of time. (Professor, Nutrition \& Dietetics) 
Table 4 Exploratory factor analysis (construct validity) and Cronbach alpha (internal reliability) tests (ordered as per factor value)

\begin{tabular}{|c|c|c|c|c|c|c|c|}
\hline & \multicolumn{6}{|c|}{ Component } & \multirow{2}{*}{$\begin{array}{l}\text { Alpha } \\
\text { value }(\alpha)\end{array}$} \\
\hline & 1 & 2 & 3 & 4 & 5 & 6 & \\
\hline Constructs & 1 & 2 & 3 & 3 & 1 & $2 / 3$ & \\
\hline I am a confident teacher & .868 & & & & & & 0.679 \\
\hline I am an innovative teacher & .794 & & & & & & \\
\hline I like to experiment with what I do as a teacher & .741 & & & & & & \\
\hline I mostly supervise master's students & .705 & & & & & & \\
\hline $\begin{array}{l}\text { Student evaluation is a valued mechanism through } \\
\text { which I develop my teaching }\end{array}$ & .578 & & & & & & \\
\hline I enjoy teaching & .560 & & & & & & \\
\hline It is important to discuss concepts with students & .512 & & & & & & \\
\hline I mostly teach undergraduates & -.502 & & & & & & \\
\hline My preferred method of teaching is enquiry-led & .412 & & & & & & \\
\hline $\begin{array}{l}\text { My preferred method of teaching is based around } \\
\text { problem-based learning }\end{array}$ & .401 & & & & & & \\
\hline $\begin{array}{l}\text { I am interested in my professional development } \\
\text { as an educator }\end{array}$ & & .939 & & & & & 0.781 \\
\hline $\begin{array}{l}\text { I am interested in my professional development } \\
\text { as a researcher }\end{array}$ & & .659 & & & & & \\
\hline $\begin{array}{l}\text { I have learnt how to teach from a combination } \\
\text { of pedagogical training, observation and speaking } \\
\text { to others }\end{array}$ & & .511 & .424 & & & .409 & 0.115 \\
\hline $\begin{array}{l}\text { I have learnt how to teach from participating on a } \\
\text { teaching programme }\end{array}$ & -.467 & .485 & .418 & & & & \\
\hline I have learnt how to teach from being watched & & .443 & & .405 & & & 0.696 \\
\hline $\begin{array}{l}\text { I would be more interested in teaching if it carried } \\
\text { greater weight }\end{array}$ & & .424 & & & & & \\
\hline I teach more often than I would like to & & & -.816 & & & & \\
\hline I teach less often than I would like to & & & .803 & & & & \\
\hline I define myself primarily as a researcher & & & & & & & \\
\hline I have learnt how to teach from talking to others & & & & 694 & & & \\
\hline $\begin{array}{l}\text { I receive the best advice about teaching from } \\
\text { disciplinary-based colleagues }\end{array}$ & & & & 671 & & & \\
\hline $\begin{array}{l}\text { I receive the best advice about teaching from } \\
\text { education-based colleagues }\end{array}$ & & & & .404 & & & \\
\hline I define myself primarily as a scientist & & & & & & & \\
\hline It is important to deliver content to students & & & & & .914 & & 0.767 \\
\hline $\begin{array}{l}\text { My preferred method of teaching is based around } \\
\text { knowledge-transfer }\end{array}$ & & & & & .752 & & \\
\hline $\begin{array}{l}\text { Peer review is a valued mechanism through which I } \\
\text { develop my teaching }\end{array}$ & & & & & & .752 & 0.499 \\
\hline I define myself primarily as a science educator & & & & & & .515 & \\
\hline I mostly teach practical sessions in a laboratory & & & & & & .470 & \\
\hline Cumulative variance explained: $68.118 \%$ & & & & & & & \\
\hline Extraction method: principal axis factoring & & & & & & & \\
\hline Extraction method: varimax with Kaiser normalisation & & & & & & & \\
\hline Kaiser-Meyer-Olkin (KMO) measure of sampling ade & quacy: 0 & 608 & & & & & \\
\hline Cronbach alpha $(\alpha): 0.697$ & & & & & & & \\
\hline
\end{tabular}

Even though the respondents had mostly spent their time in academia, the numbers who selfidentified as science educators were small (17.2\% strongly agree and 35.9\% agree) when compared to those who self-identified as scientists (28.1\% strongly agree and $42.2 \%$ agree) and researchers $(28.1 \%$ strongly agree and $50 \%$ agree) respectively. 
Another interesting insight revealed by an initial analysis of the responses suggests that knowledge transfer as a teaching method is least preferred (9.4\% strongly agree) when compared to PBL (21.9\% strongly agree) or enquiry-based teaching (26.6\% strongly agree). Perhaps unsurprisingly, and following on from this point, discussion of concepts with students is more important (43.8\% strongly agree) than delivering content to them (25.4\% strongly agree). These findings were echoed in open-text comments:

You might be surprised to find we're in a different place now. I have so many tools and resources to make my teaching more interactive. It takes time and sometimes you're pressurised into it, but it can be rewarding, and students expect this from us. (Lecturer, Mathematics)

Finally, the analysis of responses reveals that these science lecturers rely on student evaluation as a mechanism to support their CPD as teachers significantly more (17.2\% strongly agree and $43.8 \%$ agree) as compared with the use of peer review (9.4\% strongly agree and $39.1 \%$ agree). Open-text comments revealed that student evaluations can be informative, but needed to be read with care:

Students can tell me whether I'm going too fast and they're having problems with content. That's helpful. Sometimes, they can be blatantly rude though. I have felt their unkindness as have friends of mine. It's easy for them to hide as it's anonymous. (GTA, Physics)

Table 2 which depicts the Spearman Rho correlations points to some interesting insights. For example, there is a significant degree of association between items 4 (being an innovative teacher) and 15 (mostly teaching masters students) $(r=0.537, p<0.000)$. It is also worth highlighting that a significant degree of association exists between items 19 (accepted identity of science educator) and 27 (developing practice through peer review) $(r=0.412, p<0.000)$. The items related to being self-confident (item 2) and making use of student evaluation to develop taught practice (item 28) demonstrate a significant degree of association $(r=0.504$, $p<0.000)$. It is worth noting the significant degree of association $(r=0.470, p<0.000)$ between item 8 (interest in CPD as an educator) and item 10 (greater interest in teaching if it carried greater weight). In terms of insignificant degrees of association, there is a significant negative correlation between being a confident teacher (item 2) and learning to teach through pedagogical training (item 23) $(r=-0.575)$. Similarly, there is also a significant negative correlation between confidence and learning to teach from education-based colleagues (item 26) $(r=-0.461)$. Finally, the correlation between items 12 (teaching by discussing concepts) and 23 also reveals a negative association between $(r=-0.431)$.

Items have been used to generate the regression model rather than constructs. The rationale for this is that if constructs were used, rather than each item in turn, important subtleties would have been missed. Science lecturers are prepared as teachers go through many overlapping and varied mechanisms that exist both inside and outside of academic practice. Some of these nuances may have been missed if the modelling had focused on the main constructs generated from the EFA rather than the individual items.

The models generated are presented:

Model 1

- Confident teacher $=0.121+0.126 *$ supervising masters students +0.437 *enjoying teaching $+-0.396 *$ participating with pedagogical training $+0.428 *$ being an innovative teacher 
Model 2

- Confident teacher $=-0.042+0.417 *$ enjoying teaching $+-0.373 *$ participating with pedagogical training $+0.520 *$ being an innovative teacher $+-0.441 *$ receiving good advice from education-based colleagues $+0.302 *$ acknowledging the importance of content + $0.295 *$ combination of being observed, talking to others and participating with pedagogical training

A model summary indicating correlation between observed and predicted values of dependent variables, as the models are built up, is provided (Table 5).

The items that appear in the 2 models were not selected, but rather produced by the SPSS software. Table 5 provides a summary of how the regression models were generated, step by step through this programme. All items from the survey were inserted into the programme as independent variables with the exception of item 2-I am a confident teacher, which served as the dependant variable (a proxy for preparedness), against which all other items were measured. In considering Table 5, each construct is broad in nature, and therefore even though it may appear a little unusual that items from the same construct appear as both the dependent variable and as an independent variable, it is not entirely unexpected. For example, the model shows that acquiring confidence as a teacher is dependent upon being innovative (both items are from construct 1) - the construct itself relates to personal and professional values and beliefs, which conceivably could and often do influence one another in developing teaching practice.

Table 5 Model summary data (forward, stepwise at 95\% confidence interval)

\begin{tabular}{lllll}
\hline Model & $R$ & $R$-square & Adjusted $R$-square & Std. error of the estimate \\
\hline 1 & $.623^{\mathrm{a}}$ & .389 & .378 & .45920 \\
2 & $.709^{\mathrm{b}}$ & .503 & .487 & .41737 \\
3 & $.781^{\mathrm{c}}$ & .610 & .589 & .37319 \\
4 & $.829^{\mathrm{d}}$ & .687 & .665 & .33736 \\
5 & $.821^{\mathrm{e}}$ & .674 & .658 & .34086 \\
6 & $.855^{\mathrm{f}}$ & .732 & .713 & .31210 \\
7 & $.876^{\mathrm{g}}$ & .768 & .747 & .29301 \\
8 & $.893^{\mathrm{h}}$ & .798 & .776 & .27559 \\
\hline
\end{tabular}

a Predictors: (Constant), I mostly supervise master's students

b Predictors: (Constant), I mostly supervise master's students, I enjoy teaching

c Predictors: (Constant), I mostly supervise master's students, I enjoy teaching, I have learnt how to teach from participating on a teaching programme

d Predictors: (Constant), I mostly supervise master's students, I enjoy teaching, I have learnt how to teach from participating on a teaching programme, I am an innovative teacher

e Predictors: (Constant), I enjoy teaching, I have learnt how to teach from participating on a teaching programme, I am an innovative teacher

f Predictors: (Constant), I enjoy teaching, I have learnt how to teach from participating on a teaching programme, I am an innovative teacher, I receive the best advice about teaching from education-based colleagues

g Predictors: (Constant), I enjoy teaching, I have learnt how to teach from participating on a teaching programme, I am an innovative teacher, I receive the best advice about teaching from education-based colleagues

h Predictors: (Constant), I enjoy teaching, I have learnt how to teach from participating on a teaching programme, I am an innovative teacher, I receive the best advice about teaching from education-based colleagues, It is important to deliver content to students, I have learnt how to teach from a combination of pedagogical training, being observed and talking to others 


\section{Discussion}

The results from the survey and first phase of analysis suggest some interesting insights. Firstly, communities of practice are established with disciplinary-based communities proving more beneficial than those that are education-based; the support of disciplinary-based colleagues is a positive impact on novice lecturers, especially in terms of developing their understanding of scholarship (Cox 2013). Secondly, the pull of the discipline is significant here, although notions of science lecturer are changing with suggestions from US-based research that these individuals ought to possess an educational specialism and that although their research might be science-based, they would be expected to lend their educational expertise to specific areas of teaching and learning (Bush et al. 2011; Addy et al. 2015). Thirdly, science lecturers require a content knowledge base, but increasingly are becoming more innovative and active in their approaches, especially when teaching higher order learning skills (for example Farmer et al. 2008) to students who are arguably more enquiring and mature in their approach to learning when compared with undergraduate students. Fourthly, review processes are a bit of a mixed blessing. Peer review processes certainly invite reflection in such a way that constructive dialogue ensues on the skills, capabilities and values and beliefs of a discipline-based educator (Huston and Weaver 2008). The comments and statistical correlations between student evaluation and developing confidence suggest a slight weariness of, and equally importance given to students' evaluations, especially if associated with prizes awarded by students that recognise outstanding teaching (Macfarlane 2011). Finally, recognition matters. This assertion is of interest as it highlights 'self-care' (as mentioned earlier) and the notion that teaching can become perfunctory and stale in design and delivery if it is not attached to reward and recognition (Harland and Wald 2018), which is often the case in research-intensive HEIs especially.

The confidence models (which equate to authentic preparation here) generated through regression modelling present us with some interesting insights, not least that we are presented with 2 models. Model 1 suggests authenticity in preparing to teach is built through acquiring an excellent grasp of the material, enjoying oneself and having the autonomy to be innovative. This model centres on teaching master's level students, who are motivated, self-regulated learners and are often supervised in small groups, which may imply that lecturers think less hard about additional preparation or are simply confident about teaching them. Additionally, the taught content during these supervised sessions usually stems from the expertise of the lecturer, which again is something they are naturally confident about (Artino Jr. and Stephens 2009). Model 2 suggests some of the same, but importantly for academic developers, a holistic and broad-based approach to academic practice is required, rather than one that merely focuses on introducing pedagogies, and the relationship between academic developers and science lecturers needs to be reimagined for it to be of benefit.

Breaking the models down further, item 4 , which refers to being innovative as a teacher, is included as a significant factor in both models. One might expect this to be the case as earlier research indicates that it is often a lack of confidence which leads science lecturers to adopt a survival mode and teach in a sedate, traditional manner for the transmission of knowledge as mentioned earlier, exercising a degree of nervousness and actively desisting a more negotiated or open teaching framework (Kind 2009; Dreon and McDonald 2012). Furthermore, work carried out by Postareff and Lindblom-Ylänne (2011) resonates with these findings in contending that confidence is high among lecturers with a consonant learning-focused profile who are confident about mastering content and being able to teach their students. Mastery of 
content is important here (knowledge of discipline was cited as a criterion of authenticity). However, according to research carried out by Sadler (2013), lecturers who possess good content knowledge and are confident about what they know are more prepared to take risks implying the existence of a cyclic relationship between content, confidence and interactivity and innovation in teaching. To this one could add the importance of open dialogue and selfreflection as being pivotal spaces in which lecturers effectively stop and think and determine how to do better. A much earlier model (Kugel 1993), based on survey data, implied that open dialogue is an important part of the process in developing teaching practice. Similar findings are reported in this research by the confidence models, which includes self (enjoying teaching) followed by subject (acknowledging the importance of content). It would be interesting to inquire further as to whether science lecturers, especially the more experienced ones, could chart their progression with respect to the models mentioned here and whether many factors have effectively combined to support their progression (represented by the confidence model) or active/independent learning on the part of the student (represented by Kugel's model) are part of their development story.

As part of this discussion, it is important to establish what further work needs to be done by academic developers that benefits science lecturers in bettering their taught practice, based on these findings, and related to their authentic preparation. Pedagogical training does have a part to play here, but only when it is part of a combined offering (that includes observation and constructive conversation) and needs to be embedded in some form of collective discourse, although our models suggest that advice is not always helpful. Peer-to-peer support and open dialogue in informal settings (represented as item 22 on the administered survey) may prove more meaningful (Deaker et al. 2016). Theme-based cross-disciplinary networks and open meetings may prove valuable here in facilitating this form of useful conversation. Learning in networks and peer coaching are valued as potentially powerful mechanisms for supporting professional development of teaching practice (van Driel et al. 2001). Emotions are also brought out and can be dealt with via peer support mechanisms as these are central to the development of teaching practice as positive emotions, such as enjoyment, are related to the adoption of a student-focused, conceptual change approach to teaching (Trigwell 2009; Postareff and Lindblom-Ylänne 2011). Similarly, peer observation has been shown to be effective in developing confidence in university lecturers before now, (as also highlighted by the confidence model), but the process requires an established protocol that is agreed by all concerned for it to be beneficial in prompting meaningful reflection; if done properly, it may even sit comfortably alongside student evaluation as a truer account of lecturers' ability, skills and continual development as educators (Dillon et al. 2020).

Furthermore, one way in which lecturers can feel emotionally positive about their teaching is by ensuring that departmental policies enable them to begin their teaching careers teaching topics they have most familiarity with (Sadler 2013). Equally, how is innovative thinking built in to teaching preparation given the importance of this as a factor in developing confidence among lecturers? The integration of technology and team-teaching methods may serve as useful ways in which the teacher becomes more innovative (Jang 2008). A problem-based approach that connects science with society is another suggested teaching strategy that leads to innovation through experiment, focusing on the big ideas of science (Holbrook 2010). In relation to this point, it may seem necessary to convince science lecturers, especially novice ones, of the value of innovation and experimentation in teaching which may entail dropping some of the content from the curriculum to make way for activity in the classroom - a difficult balance to strike given earlier comments about a good grasp of technical knowledge. 
According to previous research, teachers adopt constructivist approaches to teaching in the same way that students adopt constructivist approaches to learning (Feldman 2000; Davis 2002). Therefore, the theories that guide teaching must be dispensed with and new ones adopted by virtue of dissatisfaction. Institutional strategies may facilitate this process as there is an increasing understanding of the benefits of engaging the student through active learning techniques such as flipping the classroom which, by its very nature, requires the lecturer to be experimental and innovative (Berrett 2012).

\section{Concluding Remarks}

In conducting this study, it has been possible to develop some preliminary models based on survey data looking at the authenticity of preparation of science lecturers at a researchintensive HEI in the UK. Even though the models are based on a small sample size with 64 participants, and generalisability may not seem possible, these models are useful in putting down a marker by providing an initial, visual appreciation of how authentic teaching practice is acquired. It is hoped that they open the floor for further critique, discussion and development with respect to authentic preparation among science lecturers for their role as teachers.

Being innovative and experimental, developing a disciplinary-based peer-to-peer network and having a good grasp of technical knowledge are some of the authentic practices that support science lecturers in developing their teaching skills. As part of this work, it is possible to establish how academic practice may evolve somewhat - pedagogical training is important for instilling confidence (the measure used here to demonstrate preparedness), but only as part of a broader package of support. Equally, institutional support may be required, for example by enabling new lecturers to teach subjects they are familiar with in the first instance so confidence and subsequently enjoyment is naturally developed. Additionally, HEIs could do more to introduce funding and support that encourages teachers to develop interactive pedagogies, and strategies that are aimed at teaching carrying greater leverage and importance. Change is taking place albeit slowly, but by surfacing the authentic journey science lecturers go on in preparing to teach, it is possible to see how academic developers might work more closely with this group to support them and expedite such change.

Funding Funding for this project was received through an internal grant.

\section{Compliance with Ethical Standards}

Conflict of Interest The authors declare that they have no conflict of interest.

\section{Ethical Approval LRS-15/16-3237}

Open Access This article is licensed under a Creative Commons Attribution 4.0 International License, which permits use, sharing, adaptation, distribution and reproduction in any medium or format, as long as you give appropriate credit to the original author(s) and the source, provide a link to the Creative Commons licence, and indicate if changes were made. The images or other third party material in this article are included in the article's Creative Commons licence, unless indicated otherwise in a credit line to the material. If material is not included in the article's Creative Commons licence and your intended use is not permitted by statutory regulation or exceeds the permitted use, you will need to obtain permission directly from the copyright holder. To view a copy of this licence, visit http://creativecommons.org/licenses/by/4.0/. 


\section{References}

Addy, C. L., Browne, T., Blake, E. W., \& Bailey, J. (2015). Enhancing inter professional education: Integrating public health and social work perspectives. American Journal of Public Health, 105(1), 106-108.

Artino Jr., A. R., \& Stephens, J. M. (2009). Academic motivation and self-regulation: A comparative analysis of undergraduate and graduate students learning online. The Internet and Higher Education, 12(3-4), 146-151. https://doi.org/10.1016/j.iheduc.2009.02.001.

Berrett, D. (2012). How "flipping" the classroom can improve the traditional lecture. The Chronicle of Higher Education, 58(25), 16-18.

Borko, H., \& Putnam, R. T. (1996). Learning to teach. In D. C. Berliner \& R. C. Calfee (Eds.), Handbook of Educational Psychology (pp. 673-708). New York: Macmillan.

Boud, D., \& Brew, A. (2013). Reconceptualising academic work as professional practice: Implications for academic development. International Journal for Academic Development, 18(3), 208-221. https:/doi. org/10.1080/1360144X.2012.671771.

Bush, S. D., Pelaez, N. J., Rudd, J. A., Stevens, M. T., Tanner, K. D., \& Williams, K. S. (2011). Investigation of science faculty with education specialties within the largest university system in the United States. $C B E-$ Life Sciences Education, 10(1), 25-42. https://doi.org/10.1187/cbe.10-08-0106.

Carew, A. L., Lefoe, G., Bell, M., \& Armour, L. (2008). Elastic practice in academic developers. International Journal for Academic Development, 13(1), 51-66. https://doi.org/10.1080/13601440701860250.

Cox, M. D. (2013). The impact of communities of practice in support of early-career academics. International Journal for Academic Development, 18(1), 18-30. https://doi.org/10.1080/1360144X.2011.599600.

Cranton, P., \& Carusetta, E. (2004). Perspectives on authenticity in teaching. Adult Education Quarterly, 55(1), 5-22. https://doi.org/10.1177/0741713604268894.

Davis, K. S. (2002). 'Change is hard': What science teachers are telling us about reform and teacher learning of innovative practices. Science Education, 87(1), 3-30. https://doi.org/10.1002/sce.10037.

Deaker, L., Stein, S. J., \& Spiller, D. (2016). You can't teach me: Exploring academic resistance to teaching development. International Journal for Academic Development, 21(4), 299-311. https://doi.org/10.1080 /1360144X.2015.1129967.

Dillard, C. (2006). On spiritual strivings. Transforming an African American woman's academic life. New York: State University of New York Press.

Dillon, H., James, C., Prestholdt, T., Peterson, V., Salomone, S., \& Anctil, E. (2020). Development of a formative peer observation protocol for STEM faculty reflection. Assessment \& Evaluation in Higher Education, 45(3), 387-400. https://doi.org/10.1080/02602938.2019.1645091.

Dreon, O., \& McDonald, S. (2012). Being in the hotspot: A phenomenological study of two beginning teachers' experiences enacting inquiry science pedagogy. Teachers and Teaching: Theory and Practice, 18(3), 297313. https://doi.org/10.1080/13540602.2012.629837.

Farmer, B., Yue, A., \& Brooks, C. (2008). Using blogging for higher order learning in large cohort university teaching: A case study. Australasian Journal of Educational Technology, 24(2), 123-136. https://oi. org/10.14742/aject.1215.

Feldman, A. (2000). Decision making in the practical domain: A model of practical conceptual change. Science Education, 84, 606-623. https://doi.org/10.1002/1098-237X(200009)84:5<606::AID-SCE4>3.0.CO;2-R.

Fraser, S. P. (2015). Pedagogical content knowledge (PCK): Exploring its usefulness for science lecturers in higher education. Research in Science Education, 46, 141-161. https://doi.org/10.1007/s11165-014-9459-1.

Freeman, S., Eddy, S. L., McDonough, M. K., Okoroafor, N., Jordt, H., \& Wenderoth, M. P. (2015). Active learning increases student performance in science, engineering and mathematics. Proceedings of the National Academy of Sciences, 111(23), 8410-8415.

Friedrichsen, P., \& Dana, T. (2005). A substantive-level theory of highly-regarded secondary biology teachers' science teaching orientations. Journal of Research in Science Teaching, 42, 218-244. https://doi. org/10.1002/tea.20046.

Gilmour, A., Welply, A., Cowpe, J., Bullock, A. D., \& Jones, R. J. (2016). The undergraduate preparation of dentists: Confidence levels of final year dental students at the School of Dentistry in Cardiff. British Dental Journal, 221, 349-354. https://doi.org/10.1038/sj.bdj.2016.686.

Guilbault, M. (2018). Students as customers in higher education: The (controversial) debate needs to end. Journal of Retailing and Consumer Services, 40, 295-298. https://doi.org/10.1016/j.retconer.2017.03.006.

Hamilton, M. (2018). Pedagogical transitions among science teachers: How does context intersect with teacher beliefs? Teachers and Teaching: Theory and Practice, 24(2), 151-165. https://doi.org/10.1080 $/ 13540602.2017 .1367658$.

Handelsman, J., Ebert-May, D., Beichner, R., Bruns, P., Cheng, A., DeHaan, R., Gentile, J., Lauffer, S., Stewad, J., Tilghnan, S. M., \& Wood, N. B. (2004). Scientific teaching. Science, 304(5670), 521-522. https://doi. org/10.1126/science.1096022. 
Harland, T., \& Wald, N. (2018). Vanilla teaching is a rational choice: The impact of research and compliance on teacher development. Teaching in Higher Education, 23(4), 419-434. https://doi.org/10.1080 $/ 13562517.2017 .1395408$.

Holbrook, J. (2010). Education through science as a motivational innovation for science education for all. Science Education International, 21(2), 80-91 ISSN: ISSN-2077-2327.

Huston, T., \& Weaver, C. L. (2008). Peer coaching: Professional development for experienced faculty. Innovative Higher Education, 33(1), 5-20. https://doi.org/10.1007/s10755-007-9061-9.

Jang, S. J. (2008). Innovations in science teacher education: Effects of integrating technology and team-teaching strategies. Computers and Education, 51(2), 646-659. https://doi.org/10.1016/j.compedu.2007.07.001.

Kember, D., \& Kwan, K. P. (2000). Lecturers' approaches to teaching and their relationship to conception of good teaching. Instructional Science, 28, 469-490. https://doi.org/10.1023/A:1026569608656.

Kind, V. (2009). A conflict in your head: An exploration of science lecturers subject matter knowledge development and its impact on teacher self-confidence. International Journal of Science Education, 31(11), 1529-1562. https://doi.org/10.1080/09500690802226062.

Kreber, C. (2010). Academics' teacher identities, authenticity and pedagogy. Studies in Higher Education, 35(2), 171-194. https://doi.org/10.1080/03075070902953048.

Kreber, C., Klampfleitner, M., McCune, V., Bayne, S., \& Knottenbelt, M. (2007). What do you mean by 'authentic?' A comparative review of the literature on conceptions of authenticity in teaching. Adult Education Quarterly, 58(1), 22-43. https://doi.org/10.1177/0741713607305939.

Kugel, P. (1993). How professors develop as teachers. Studies in Higher Education, 18(3), 315-328. https://doi. org/10.1080/03075079312331382241.

Macfarlane, B. (2011). Prizes, pedagogic research, and teaching professors: Lowering the status of teaching and learning through bifurcation. Teaching in Higher Education, 16(1), 127-130. https://doi.org/10.1080 /13562517.2011.530756.

Magolda, B. (2004). Evolution of a constructivist conceptualization of epistemological reflection. Educational Psychologist, 39(1), 31-42. https://doi.org/10.1207/s15326985ep3901_4.

Noddings, N. (2003). Caring: A feminine approach to ethics and moral education (2nd ed.). Berkeley: University of California Press.

Palmer, P. (1998). The courage to teach: Exploring the inner landscape of a teacher's life. San Francisco: JosseyBass.

Patterson, C. (1973). Humanistic education. Englewood Cliffs: Prentice-Hills.

Postareff, L., \& Lindblom-Ylänne, S. (2011). Emotions and confidence within teaching in higher education. Studies in Higher Education, 36(7), 799-813. https://doi.org/10.1080/03075079.2010.483279.

Roxå, T., \& Mårtensson, K. (2017). Agency and structure in academic practices: Are we liberating academic teachers or are we part of a machinery suppressing them? International Journal for Academic Development, 22(2), 95-105. https://doi.org/10.1080/1360144X.2016.1218883.

Sadler, I. (2013). The role of self-confidence in learning to teach in higher education. Innovations in Education and Teaching International, 50(2), 157-166. https://doi.org/10.1080/14703297.2012.760777.

Sawir, E. (2011). Academic staff response to international students and internationalising the curriculum: The impact of disciplinary differences. International Journal for Academic Development, 16(1), 45-57. https://doi.org/10.1080/1360144X.2011.546224.

Smith, M., Lennon, M. A., Brook, A. H., \& Robinson, P. G. (2006). A randomized controlled trial of outreach placement's effect on dental students' clinical confidence. Journal of Dental Education, 70, 566-570. https://doi.org/10.1002/j.0022-0337.2006.70.5.tb04112.x.

Taber, K. S. (2018). The use of Cronbach's alpha when developing and reporting research instruments in science education. Research in Science |Education, 48(6), 1273-1296. https://doi.org/10.1007/s11165-016-9602-2.

Trigwell, K. (2009). Relations between teachers' emotions in teaching and their approaches to teaching in higher education: A pilot study, Paper presented at the biannual international meeting for the European Association for Learning and Instruction (EARLI) 25-28th August, Amsterdam, the Netherlands.

Van Driel, J. H., Beijaard, D., \& Verloop, N. (2001). Professional development and reform in science education: The role of teachers' practical knowledge. Journal of Research in Science Teaching, 38(2), 137-158. https://doi.org/10.1002/1098-2736(200102)38:2<137::AID-TEA1001>3.0.CO;2-U.

Publisher's Note Springer Nature remains neutral with regard to jurisdictional claims in published maps and institutional affiliations. 